\title{
Sedative effects of the essential oil from the leaves of Lantana camara occurring in the Republic of Benin via inhalation in mice
}

\section{$\operatorname{AUTHOR}(\mathrm{S}):$}

Dougnon, Godfried; Ito, Michiho

\section{CITATION:}

Dougnon, Godfried ... [et al]. Sedative effects of the essential oil from the leaves of Lantana camara occurring in the Republic of Benin via inhalation in mice. Journal of Natural Medicines 2020, 74: 159-169

\section{ISSUE DATE:}

2020-01

URL:

http://hdl.handle.net/2433/245426

\section{RIGHT:}

This is a post-peer-review, pre-copyedit version of an article published in 'Journal of Natural Medicines'. The final authenticated version is available online at: https://doi.org/10.1007/s11418-019-01358-9.; The full-text file will be made open to the public on 24 August 2020 in accordance with publisher's 'Terms and Conditions for Self-Archiving'; This is not the published version. Please cite only the published version.; この論文は出版社版でありません。引用の際には出 版社版をご確認ご利用ください。 
Title: Sedative effects of the essential oil from the leaves of Lantana camara occurring in the Republic of Benin via inhalation in mice

Authors: Godfried Dougnon and Michiho Ito*

Department of Pharmacognosy, Graduate School of Pharmaceutical Sciences, Kyoto University, 46-29 Yoshida-Shimoadachi-cho, Sakyo-ku, Kyoto 606-8501, Japan

* Corresponding author:

E-mail: michihoi@pharm.kyoto-u.ac.jp

Tel: +81-75-753-4506 


\section{Abstract}

Lantana camara Linn. (Verbenaceae) is used traditionally for its numerous medicinal properties such as antimalarial, antibacterial, anticancer and anti-inflammatory. In the present study, we investigated the chemical composition of essential oil from the leaves of L. camara (LCEO) occurring in the Republic of Benin (West Africa) in comparison with LCEOs from other regions; evaluated its sedative effects in mice via inhalation administration; and identified the compounds responsible for activity. LCEO was extracted by hydrodistillation and chemical analyses of the oil were performed by GC and GC/MS. The oil was dominated by monoterpene hydrocarbons (60.58\%) and oxygenated monoterpenes (33.39\%), among which sabinene (38.81\%) and 1,8-cineole (28.90\%) were the most abundant. LCEO administered via inhalation to mice significantly decreased locomotor activity in a dose-dependent manner, mainly at the doses of 0.0004 and 0.04 mg per $400 \mu \mathrm{L}$ of triethyl citrate (TEC). The oil was fractionated to give two fractions, which were further investigated, and revealed that both sabinene and 1,8-cineole were the principal active compounds. The results of the present study indicated that via inhalation administration, LCEO and its main constituents could be considered as promising candidates for the management of dementia, insomnia, attention deficit hyperactivity disorder and other central nervous system-associated diseases.

Keywords: Lantana camara essential oil, vapor inhalation, GC/MS, sedative effect, sabinene, 1,8-cineole 


\section{Introduction}

Lantana camara Linn (Verbenaceae), the most widespread species of the Lantana genus, is an evergreen climbing aromatic shrub that can grow up to 2-4 $\mathrm{m}$ in height. The flowers are small, tubular and are various colors, from red to pink, white, yellow, and violet. The stems are quadrangular, and generally armed with hooked prickles. The fruits are green and turn black when ripe [1]. L. camara is native to tropical and sub-tropical regions of America and has now been introduced as an ornamental plant in various parts of the world. The main chemotypes reported in the literature are sesquiterpene hydrocarbons, namely ß-caryophyllene, germacrene $\mathrm{D}$, and bicyclogermacrene; monoterpenes are represented by limonene, sabinene, and ß-phellandrene; and the oxygenated compounds are mainly davanone, 1,8-cineole, caryophyllene oxide, and (E)-nerolidol [2, 3].

L. camara is used in many parts of the world to treat a number of disorders. In Tanzania, it is used to treat malaria [4], whereas in India, essential oil from the leaves is used for its antiseptic and antifungal properties [5]. In the Republic of Benin, leaves are used in traditional medicine to treat skin diseases [6], and essential oil from the leaves of L. camara (LCEO) is claimed to demonstrate sedative effects via inhalation administration. Several aromatic natural medicines have been used as incense and perfume for their relaxing or energizing effects $[7,8]$, and excellent results were obtained using essential oils in young patients suffering from attention deficit hyperactivity disorder (ADHD) [9]. Also, inhalation administration of the vapor of herbal drug oil has caused significant decrease in mice locomotor activity and this supports the argument for their traditional usage as relaxing and possible anxiolytic or antidepressant agents via inhalation administration [10-14] . To our best knowledge, only a few data are available 
concerning the chemical composition of LCEO occurring in Benin and its sedative effects remain not yet studied.

Therefore, in the present paper, the chemical composition of LCEO occurring in Benin was investigated as well as its sedative effects in mice via inhalation administration, and the components responsible for the sedative activity were identified.

\section{Material and methods}

\section{Materials}

Fresh leaves of L. camara (Supplementary data, Figure S1) were collected in October 2016 from Houedo in the Republic of Benin (West Africa) and air dried. GPS coordinates of the collection site were latitude $6^{\circ} 33^{\prime} 37.133^{\prime \prime}$ and longitude $2^{\circ} 22^{\prime 26.567 " .}$ Identification was confirmed by Gaudence Julien Djego of the Laboratory of Botany and Applied Ecology, University of Abomey-Calavi, and vouchers were deposited in the Herbarium of Experimental Station for Medicinal Plants, Graduate School of Pharmaceutical Sciences, Kyoto University, Japan (specimen number EST-5024) and the National Herbarium of Benin (specimen number AA 6677/HNB). Benzylacetone (purity: 95\%, Tokyo Kasei, Japan), a well-known sedative agent [10, 13, 14], was used as a positive control. Triethyl citrate (TEC; Merck, Darmstadt, Germany), a non-sedating odorless solvent, was used to dissolve the fragrant components. Sabinene (purity: $\geq 97 \%$ ) was purchased from Chem Cruz Chemicals, Santa Cruz Biotechnologies (Dallas, USA). 1,8-Cineole (purity: > 85\%) was purchased from Wako Pure Chemical Industries, Ltd (Osaka, Japan). All chemicals used were of the highest grade available.

\section{Distillation of fresh leaves of $L$. camara and fractionation of their oil}


LCEO was extracted by hydrodistillation of L. camara leaves (56.60 g) for $2 \mathrm{~h}$ using a Clevenger apparatus as recommended in the Japanese Pharmacopoeia (JP17; http://jpdb.nihs.go.jp/jp17e/). The oil was captured in hexane, dried over anhydrous sodium sulfate, and concentrated. The headspace of the oil was then analyzed by Solid Phase Micro Extraction (SPME)-GC/MS to confirm that the oil was free of hexane. The obtained oil was stored in sealed vials at $4{ }^{\circ} \mathrm{C}$ until analysis. LCEO was subjected to silica gel column chromatography for fractionation (column diameter: $16 \mathrm{~mm}$; column height: $170 \mathrm{~mm})$, and the column was eluted with hexane/acetone (4:1, about $250 \mathrm{~mL})$ to give fractions 1 and 2. Both fractions were evaporated and subjected to GC/MS analysis to confirm that no remaining solvent was present before analysis of biological activity.

\section{GC and GC/MS analysis}

Qualitative analysis of LCEO was carried out using an Agilent 6850 series gas chromatograph connected to an MSD 5975 system (Agilent Technologies). The following operating conditions were employed: column, fused silica capillary column, DB-wax (HP), $60 \mathrm{~m} \times 0.25 \mathrm{~mm} \times 0.25 \mu \mathrm{m}$; column temperature, $60-200{ }^{\circ} \mathrm{C}$, increasing at a rate of $2{ }^{\circ} \mathrm{C} / \mathrm{min}$, holding at $65{ }^{\circ} \mathrm{C}$ for $5 \mathrm{~min}$, increasing at $0.5^{\circ} \mathrm{C} / \mathrm{min}$ until $77^{\circ} \mathrm{C}$ then at $20{ }^{\circ} \mathrm{C} / \mathrm{min}$, and holding at $200{ }^{\circ} \mathrm{C}$ for $5 \mathrm{~min}$. Injector temperature, $160{ }^{\circ} \mathrm{C}$; carrier gas, helium, $25 \mathrm{~cm} / \mathrm{s}$; column head pressure, $100 \mathrm{kPa}$; ionization energy, $70 \mathrm{eV}$; injection volume, $1.0 \mu \mathrm{L}$; MS interface temperature, $150^{\circ} \mathrm{C} / \mathrm{min}$; MS mode, electron impact (EI); detector voltage, $0.4 \mathrm{kV}$; mass range, 35-300 u; scan speed, $300 \mathrm{u} / \mathrm{s}$.

Quantitative analysis was carried out on a gas chromatography (GC) system (G5000, Hitachi) equipped with a flame ionization detector (FID) as follows: column, fused silica capillary column, TC-wax (HP), $60 \mathrm{~m} \times 0.25 \mathrm{~mm} \times 0.25 \mu \mathrm{m}$; column temperature, 
as for GC/MS. Injector, $200{ }^{\circ} \mathrm{C}$; detector, FID, $220{ }^{\circ} \mathrm{C}$; carrier gas, helium, 0.8 $\mathrm{mL} /$ minute; split ratio, 100:1; column head pressure, $200 \mathrm{kPa}$; injection volume, $1 \mu \mathrm{L}$. The linear retention indices of each constituent were determined using n-alkanes as standards. Chemical compounds were identified by comparing their retention indices (RI) and mass spectra (MS) using NIST Special Database 2 (https://www.nist.gov/srd/nistspecial-database-2) or by comparison with authentic samples.

\section{Animals}

Four-week-old male ddY mice (20-30 g) were purchased from Japan SLC (Shizuoka, Japan). Animals were housed in colony cages under a 12 h/12 h light/dark cycle at $25 \pm$ $2{ }^{\circ} \mathrm{C}$ and a relative humidity of $50-60 \%$. They were fed pellet chow and water ad libitum and allowed to accommodate to these conditions for 1 week before experiments. Animal experiments were conducted following the recommendations of the Animal Research Committee of Kyoto University, Kyoto, Japan (approval number, 2014-14-3). Experimental procedures involving animals and their care were conducted in accordance with the institutional guidelines and in compliance with the Fundamental Guidelines for Proper Conduct of Animal Experiment and Related Activities in Academic Research Institutions under the jurisdiction of the Ministry of Education, Culture, Sports, Science and Technology, Japan (2006). All experiments were conducted between 10:00 and 17:00 under identical conditions.

\section{Open-field test}

The sedative effects of LCEO on mice were evaluated using an open-field test, as previously described [10]. The open-field arena is represented in Supplemental data, 
Figure S2. Administered doses were expressed as milligrams of sample per $400 \mu \mathrm{L}$ of TEC, following previous experiments [11, 14-16]. Four pieces of filter paper were placed in the four corners of the inner walls of the glass cage $(60 \mathrm{~cm}$ wide, $30 \mathrm{~cm}$ long, $34 \mathrm{~cm}$ high) using adhesive tape. A sample was deposited on each piece of filter paper and the cage was closed so that the vapor pervaded by natural diffusion. Sixty minutes after charging the sample, a mouse was placed in the center of the cage and subjected to video surveillance for another $60 \mathrm{~min}$. During monitoring, the frequency each mouse crossed lines drawn at $10 \mathrm{~cm}$ intervals on the floor of the cage was counted every $5 \mathrm{~min}$. The Area under the curve (AUC) of locomotor activity counts per 5 min (y-axis) and time (x-axis), representing total locomotor activity, was calculated by trapezoidal rule.

\section{Amount of compound evaporated in the cage before inserting the mice}

The amount of compound evaporated in the glass cage was measured using methodology previously described $[8,17]$. Each compound was dissolved in TEC and dropped onto a filter paper. The filter paper was weighed and placed in a closed glass cage for $60 \mathrm{~min}$, after what it was removed and weighed again. Weight difference from immediately after dropping the sample and after removal of the filter paper was regarded as the amount of compound evaporated per hour in the glass cage.

\section{Statistical analysis}

All values are expressed as the mean \pm standard error of mean (SEM). Statistical analyses were performed using Student's t-test or one-way analysis of variance (ANOVA) followed by Dunnett's multiple comparison test using GraphPad InStat software 
(GraphPad Software, San Diego, CA, USA). A probability level of $\mathrm{p}<0.05$ was considered to be statistically significant.

\section{Results and Discussion}

\section{GC and GC-MS analyses of LCEO}

The results of the GC and GC/MS analyses of LCEO are presented in Table 1 according to their retention indices on a DB-wax column and are compared in their ratio with LCEOs from other regions. In the present study, a total of 13 compounds were identified, with the main components being represented by monoterpene hydrocarbons (60.58\%) and oxygenated monoterpenes (33.39\%); sabinene and 1,8-cineole (38.81\% and $28.90 \%$ respectively) were the main ones (Figure 1). Similar to our study, a previous work conducted in another region of the Republic of Benin (Seme) showed that the main compounds of LCEO were sabinene (21.5\%) and 1,8-cineole (23.4\%) [18]. LCEO is known to demonstrate an important quantitative and qualitative variability in the chemical contents of its oil. Therefore, we compared the results in our present study with previous studies on LCEOs from different regions.

Our results showed similar qualitative composition with LCEOs from Nigeria (wild), Cameroon, and Madagascar (cultivated), which all contained sabinene, 1,8cineole, $\alpha$-pinene, and ß-caryophyllene at various concentrations $[19,20]$, whereas LCEO from India (wild) showed notable difference with our study and contained no trace of sabinene [21]. The presence or absence of sabinene and 1,8-cineole in LCEO from northern Brazil (wild) depended on the collection site and time of collection [22, 23], whereas neither were found in LCEO from Cuba (cultivated) [24]. Citral was the major compound identified in five varieties of L. camara from Egypt (wild) [25]; however, it 
was not detected in samples from Nigeria or Benin. More, a high content of sesquiterpene hydrocarbon compounds with mainly ß-caryophyllene (13.26\%) and ar-curcumene (24.69\%) was reported in LCEO from Cameroon [20], while LCEO from China (wild) was represented by $\alpha$-humulene (9.3\%) and germacrene-D (15.8\%) [26]. Monoterpene hydrocarbons are mainly represented by $\alpha$-phellandrene (16.4\%) and limonene (16.5\%) in LCEO from northern Brazil [22], and sabinene (11.4\%), $\alpha$-pinene (4.1\%), and ß-pinene (2.8\%) in LCEO from Madagascar [27]. Among the oxygenated compounds, caryophyllene oxide (21.75\%) in LCEO from Nigeria [28], 1,8-cineole (10.75\%) in LCEO from India [21], and davanone (15.9\%) in LCEO from Madagascar [20] have mainly been reported.

The chemical composition of parts of plants is reported to be affected by the developmental stage, genetic, geographical, and seasonal factors [3, 29, 30]. Thus, the differences in chemical composition of LCEO in the present study with LCEOs from other regions could be explained by variability in climate, altitude, time of collection and soil, or the method of extraction of the oil.

\section{Sedative effects of LCEO administered to mice via inhalation}

To investigate the effects of LCEO on mice locomotor activity, mice were administered via inhalation doses of $0.000004,0.00004,0.0004,0.004,0.04$ or 0.4 mg LCEO dissolved in $400 \mu \mathrm{L}$ of TEC. Benzylacetone, a well-known sedative agent [10, 13, 14], was used as positive control and it significantly decreased mice locomotor activity by $61 \%(\mathrm{p}<0.05)$ as compared to the control group. This indicated that the experimental model for sedative activity in this study was validated. A decrease in locomotor activity was observed at all doses of LCEO in a dose-dependent manner and AUC values were significantly reduced 
at doses of $0.0004,0.004$ and $0.04 \mathrm{mg}$ by 68\%, 48\% and 67\% respectively $(\mathrm{p}<0.05)$, when compared to the control (Figure 2a). The sedative effects produced by the doses of $0.0004 \mathrm{mg}$ and $0.04 \mathrm{mg}$ LCEO were the most effective and locomotor activity dropped nearly to zero after 20-30 min of inhalation administration (Figure 2b). Previous studies on essential oils from Ocimum gratissimum, Piper guineense and Zingiber zerumbet have also reported sedative effects in a dose-dependent manner, supporting the argument that, similar to LCEO, there is a great variety of plant essential oil showing sedative activity, and possibly useful for the treatment of central nervous system-related diseases $[11,13$, 14].

The $\mathrm{LD}_{50}$ value for 1,8-cineole, one of the main components of LCEO, was 3849 $\mathrm{mg} / \mathrm{kg}$ [31]. Regarding sabinene, the other main component of LCEO, there were no adverse effects on nidation, reproduction, fetal development, or maternal survival when $224 \mathrm{mg} / \mathrm{kg} /$ day sabinene was administered orally for 6-15days to pregnant mice and rats [32]. In our study, the highest administered dose, $0.4 \mathrm{mg}$ LCEO, contains $0.15 \mathrm{mg}$ sabinene and $0.11 \mathrm{mg}$ 1,8-cineole, which are much lower than the concentrations required to induce toxicity. More, during all the experiments, abnormalities, such as an increase in urination or defecation, were not noticed.

\section{The most effective fraction contained sabinene and 1,8-cineole}

To identify the components responsible for activity, LCEO was fractionated to give two fractions which were further investigated for sedative activity. The main components of fraction 1 (367 mg, yellowish) were sabinene (33.95\%), 1,8-cineole (32.95\%), ßcaryophyllene (15.65\%), and $\alpha$-pinene (8.75\%), while fraction 2 (129 mg, pale yellow) consisted of terpinen-4-ol (61.63\%) and (+)-2-bornanone (38.37\%). The structures of the 
different components are represented in Figure 1. Both fractions were administered individually to the mice by inhalation at doses of $0.000004,0.00004,0.0004,0.004,0.04$ or $0.4 \mathrm{mg}$ per $400 \mu \mathrm{L}$ of TEC. As shown in Supplementary data, Figure S3a, fraction 2 induced a significant decrease in locomotor activity at $0.004 \mathrm{mg}(\mathrm{p}<0.05)$. Terpinen-4ol, one of the major compounds of fraction 2, causes a decrease in spontaneous locomotor activity in mice [33], and its sedative effects are greater than or equal to that of eugenol when administered at the same concentration in silver catfish [34]. The other major component of fraction 2, (+)-2-bornanone, has sedative, anesthetic, and analgesic properties [35, 36]. These two compounds therefore seem to explain the sedative activity of fraction 2.

Fraction 1 caused a significant decrease in mouse locomotor activity at doses of 0.0004, 0.004 and $0.04 \mathrm{mg}$, with the strongest effect observed at $0.004 \mathrm{mg}$ (Supplementary data, Figure S3b, $\mathrm{p}<0.05$ ). Fraction 1 appeared more effective than fraction 2, suggesting that it contained the most active components of LCEO. Of the main compounds of fraction $1, \alpha$-pinene is an antidepressant previously found to have sedative activity upon inhalation in mice $[37,38]$, whereas $\beta$-caryophyllene has been reported to possesses sedative, local anesthetic, antidepressant, and anxiolytic activity via a CB2 receptor agonist $[14,39]$. $\beta$-Caryophyllene and $\alpha$-pinene are present in relatively high amounts in fraction 1 and could therefore be responsible for the sedative effects. However, sabinene and 1,8-cineole comprised a larger portion of fraction 1 and LCEO, and therefore their sedative effects on mice were examined further.

\section{Effects of sabinene and 1,8-cineole on locomotor activity in mice}


The weight of the total administered compounds on filter paper was measured before and after the experiment for sabinene and 1,8-cineole. The weight of each compound was found to be reduced by $80-90 \%$ after administration for $1 \mathrm{~h}$, indicating that a large portion of the administered sample had effectively evaporated in the air before the mice were placed in the glass cage.

Sabinene and 1,8-cineole were administered individually to the mice by inhalation at doses of $0.000004,0.00004,0.0004,0.004,0.04$ or $0.4 \mathrm{mg}$ per $400 \mu \mathrm{L}$ of TEC. Sabinene decreased locomotor activity at all doses, with a significant effect at the doses of 0.0004 and $0.004 \mathrm{mg}$ (Figure 3a, p < 0.05). 1,8-Cineole showed a sedative effect similar to that of LCEO (Figure 3b); however, only $0.0004 \mathrm{mg}(\mathrm{p}<0.05$ when compared to control) demonstrated true sedative activity, because $0.04 \mathrm{mg}$ did not induce a significant effect and the mice displayed excitation behavior such as jumping and rearing. Similar effects have been observed for hexahydroxyzerumbone derivatives [14] and basil essential oil [40].

Sabinene, a natural bicyclic monoterpene, is one of the chemicals that contribute to the flavor of black pepper and is a major constituent of carrot and nutmeg seed oils [41]. It has also been reported to act as an anti-inflammatory agent [42]. Sabinene is a double-bond isomer of thujene, a major constituent of Hedyosmum brasiliense, which is also used as a sedative[43]; this suggested a possible sedative activity of sabinene. 1,8Cineole is a naturally occurring saturated monoterpene found mainly in the essential oils of Eucalyptus and has been reported to have smooth muscle relaxant, anti-inflammatory, and antinociceptive effects $[44,45]$. Also, the sedative effect of two Eucalyptus species was suggested to be due to their high 1,8-cineole content [46]. In the present study, we found evidence that sabinene and 1,8-cineole could be used as a potent sedative agent via 
inhalation. A future study should examine the relationship between the structure and activity of each sabinene, 1,8-cineole and their derivative compounds in order to elucidate the structural features with significant sedative activity.

\section{Effects of a mixture of sabinene and 1,8-cineole administered to mice via inhalation}

Both of the main compounds of LCEO (sabinene and 1,8-cineole) showed sedative activity, and a mixture (ratio 1:1) of these compounds was tested to understand their role in this activity. A mixture of sabinene and 1,8-cineole was administered to mice via inhalation at doses of $0.00008,0.0008,0.008,0.08$ or $0.8 \mathrm{mg}$ per $400 \mu \mathrm{L}$ of TEC, which resulted in a decrease in locomotor activity in a dose-dependent manner. Analysis of AUC values showed a significant decrease at doses of $0.0008,0.008$ and $0.08 \mathrm{mg}$ by $65 \%, 52 \%$ and $63 \%$ respectively $(\mathrm{p}<0.05$ ) as compared to the control group (Figure $4 a)$. Mice in the 0.0008 and $0.08 \mathrm{mg}$ administered groups calmed within 20-30 min (Figure 4b), as it was observed in LCEO. More, comparison of locomotor activity transition of mice treated with the mixture of sabinene and 1,8-cineole with that of mice treated with LCEO showed that their sedative activity described a similar decrease in the time course. This result suggested that both sabinene and 1,8-cineole were the principal components responsible for sedative activity of LCEO. However, it is important to observe that LCEO contained other compounds than sabinene and 1,8-cineole, and these compounds though present only in a small amount might have combined to cause a sedative activity in LCEO. Similarly, some authors have previously reported a synergistic action of various constituents present in essential oils from plant material [13, 47].

The identification of active components is an important step to investigate the effects of plant material. The doses applied to rodents are known to be very different from 
the effective doses in humans. However, the findings of the present study indicate that LCEO and its related compounds might be useful for the sedation of individuals with dementia, attention deficit hyperactivity disorder, insomnia, or other psychological disorders [8]. Previous studies on O. gratissimum, P. guineense, Microtoena patchoulii, Zingiber zerumbet, and Heracleum afghanicum [8, 11, 13-15], as well as the present paper, have shown that a number of volatile components from the essential oils of various plants potently reduce the locomotor activity in mice following inhalation administration. Studies are currently underway to investigate the relationship between the structure and activity of LCEO components, and their possible beneficial actions for the treatment of anxiety and depression. The results of these studies could lead to the use of LCEO as a natural medicine in the management of diseases related to the central nervous system.

\section{Conclusion}

A great variability in the chemical composition of LCEOs from different regions was demonstrated in the present paper. We also showed that LCEO collected during the rainy season in Houedo (Republic of Benin), possesses strong sedative activity when administered via inhalation, and the major components of the oil, namely sabinene and 1,8-cineole, were identified as principal active compounds. The reduction of locomotor activity may indicate relaxing, anxiolytic or antidepressant effects. Therefore, further investigations using animal models of anxiety and depression are now required to better understand the activities of LCEO and its related compounds.

\section{Funding: None.}

Conflict of Interest: The authors declare that they have no conflict of interest. 


\section{References}

1. Sharma O, Dawra R, Pattabhi V (1991) Molecular structure, polymorphism and toxicity of lantadene A, the pentacyclic triterpenoid from the hepatotoxic plant, Lantana camara. J Biochem Toxicol 6:57-63

2. Khan M, Mahmood A, Alkhathlan HZ (2016) Characterization of leaves and flowers volatile constituents of Lantana camara growing in central region of Saudi Arabia. Arab J Chem 9:764-774. https://doi.org/10.1016/j.arabjc.2015.11.005

3. Sonibare OO, Effiong I (2008) Antibacterial activity and cytotoxicity of essential oil of Lantana camara leaves from Nigeria. Afr J Biotechnol 7:2618-2620

4. Weenen H, Nkunya H, Bray H, et al (1990) Antimalarial activity of Tanzanian medicinal plants. Planta Med 56:368-370

5. Deena MJ, Thoppil JE (2000) Antimicrobial activity of the essential oil of Lantana camara. Fitoterapia 71:453-455

6. Alitonou G, Avlessi F, Bokossa I, et al (2004) Chemical composition and biological activities of essential oil from Lantana camara Linn. C R Chimie 7:1101-1105

7. Fujiwara Y, Ito M (2015) Synergistic Effect of Fragrant Herbs in Japanese Scent Sachets. Planta Med 81:193-199. https://doi.org/10.1055/s-0034-1396138

8. Ito K, Ito M (2011) Sedative effects of vapor inhalation of the essential oil of Microtoena patchoulii and its related compounds. J Nat Med 65:336-343. https://doi.org/10.1007/s11418-010-0502-x

9. Sinha D, Efron D (2005) Complementary and alternative medicine use in children with attention deficit hyperactivity disorder. J Paediatr Child Health 41:23-26. https://doi.org/10.1111/j.14401754.2005.00530.x

10. Takemoto H, Ito M, Shiraki T, et al (2008) Sedative effects of vapor inhalation of agarwood oil and spikenard extract and identification of their active components. J Nat Med 62:41-46

11. Tankam JM, Ito M (2013) Inhalation of the essential oil of Piper guineense from Cameroon shows sedative and anxiolytic-like effects in mice. Biol Pharm Bull 36:1608-1614. https://doi.org/10.1248/bpb.b13-00491

12. Ogawa K, Miyoshi T, Kitayama T, Ito M (2014) Locomotor-reducing effects and structural characteristics of inhaled zerumbone and tetrahydrozerumbone derivatives. Biol Pharm Bull 37:15591563

13. Tankam JM, Ito M (2014) Sedative, anxiolytic and antidepressant-like effects of inhalation of the essential oil of Ocimum gratissimum L. from Cameroon in mice. J Pharmacogn Phytochem 2:1-9

14. Ogawa K, Yabe H, Kitayama T, Ito M (2016) Locomotor-reducing activity of sesquiterpenes related to Zingiber zerumbet essential oil and hexahydrozerumbone derivatives. Biol Pharm Bull 39:10771080. https://doi.org/10.1248/bpb.b16-00141

15. Karimi AG, Ito M (2012) Sedative effect of vapor inhalation of essential oil from Heracleum afghanicum Kitamura seeds. J Essent Oil Res 24:571-577. https://doi.org/10.1080/10412905.2012.728085

16. Miyoshi T, Ito M, Kitayama T, et al (2013) Sedative effects of inhaled benzylacetone and structural features contributing to its activity. Biol Pharm Bull 36:1474-1481 
17. Ito K, Akahoshi Y, Ito M, Kaneko S (2016) Sedative effects of inhaled essential oil components of traditional fragrance Pogostemon cablin leaves and their structure-activity relationships. J Tradit Complement Med 6:140-145. https://doi.org/10.1016/j.jtcme.2015.01.004

18. Noudogbessi J, Chalard P, Figueredo G, et al (2013) Chemical compositions and physical characteristics of volatile extracts of leaves of Psidium guajava Linn and Lantana camara Linn of Benin. Res J Pharm Biol Chem Sci 4:28-38

19. Kasali A, Ekundayo O, Paul C, et al (2004) Essential oil of Lantana camara L. var. aculeate from Nigeria. J Essent Oil Res 16:582-584

20. Ngassoum MB, Yonkeu S, Jirovetz L, et al (1999) Chemical composition of essential oils of Lantana camara leaves and flowers from Cameroon and Madagascar. Flavour Frag J 14:245-250

21. Dua V, Pandey A, Dash A (2010) Adulticidal activity of essential oil of Lantana camara leaves against mosquitoes. Indian J Med Res 131:434-439

22. da Silva M, Andrade E, Zoghbi M, et al (1999) Essential oils of Lantana camara L. occurring at North Brazil. Flavour Fragr J 14:208-210

23. Sousa EO, Colares AV, Rodrigues FF, et al (2010) Effect of collection time on essential oil composition of Lantana camara Linn (Verbenaceae) growing in Brazil Northeastern. Rec Nat Prod $4: 31-37$

24. Pino J, Marbot R, Rosado A, et al (2004) Chemical composition of the essential oil of Lantana camara L. from Cuba. J Essent Oil Res 16:216-218

25. Saleh M (1974) Gas-chromatographic analysis of the essential oil of Lantana camara L. varieties. Planta Med 25:373-375. https://doi.org/10.1055/s-0028-1097957

26. Sundufu AJ, Shoushan H (2004) Chemical composition of the essential oils of Lantana camara L. occurring in South China. Flavour Fragr J 19:229-232. https://doi.org/10.1002/ffj.1292

27. Randrianalijaona JA, Ramanoelina PAR, Rasoarahona JRE, Gaydou EM (2005) Seasonal and chemotype influences on the chemical composition of Lantana camara L. Anal Chim Acta 545:4652. https://doi.org/10.1016/j.aca.2005.04.028

28. Jawonisi IO, Adoga GI (2013) Chemical constituents of essential oil of Lantana camara Linn. leaves. Br J Pharmacol Toxicol 4:155-157

29. Shah SMM, Ullah F, Shah SMH, et al (2012) Analysis of chemical constituents and antinociceptive potential of essential oil of Teucrium stocksianum Bioss collected from the North West of Pakistan. BMC Complement Altern Med 12:1200. https://doi.org/10.1186/1472-6882-12-244

30. Harraz FM, Hammoda HM, El Ghazouly MG, et al (2015) Chemical composition, antimicrobial and insecticidal activities of the essential oils of Conyza linifolia and Chenopodium ambrosioides. Nat Prod Res 29:879-882. https://doi.org/10.1080/14786419.2014.988714

31. Xu J, Hu Z-Q, Wang C, et al (2014) Acute and subacute toxicity study of 1,8-cineole in mice. Int J Clin Exp Pathol 7:1495-1501

32. Robert T, Rodney Y (2014) Essential Oil Safety, Churchill Livingstone. Elsevier

33. de Sousa DP, Nóbrega FF, de Morais LC, de Almeida RN (2009) Evaluation of the anticonvulsant activity of terpinen-4-ol. Z Naturforsch C 64:1-5. https://doi.org/10.1515/znc-2009-1-201 
34. Becker AG, Parodi TV, Heldwein CG, et al (2012) Transportation of silver catfish, Rhamdia quelen, in water with eugenol and the essential oil of Lippia alba. Fish Physiol Biochem 38:789-796. https://doi.org/10.1007/s10695-011-9562-4

35. Ash M, Ash I (2004) Handbook of green chemicals, Washington (DC): Synapse Info Resources

36. Muthukumaran P, Kumar SK, Ravichandran K (2017) Phytochemical screening, GC-MS, FT-IR analysis of methanolic extract of Curcuma caesia Roxb (black turmeric). Phcog J 9:952-956

37. Zamyad M, Abasnejad M, Esmaeili-Mahani S, Mostafavi A (2016) Alpha-pinene as the main component of Ducrosia anethifolia (Boiss) essential oil is responsible for its effect on locomotor activity in rats. Avicenna J Neuro Psycho Physio 3:1-6. https://doi.org/10.17795/ajnpp-38787

38. Yang H, Woo J, Pae AN, et al (2016) $\alpha$-Pinene, a major constituent of pine tree oils, enhances nonrapid eye movement sleep in mice through GABAA-benzodiazepine receptors. Mol Pharmacol 90:530-539. https://doi.org/10.1124/mol.116.105080

39. Bahi A, Al Mansouri S, Al Memari E, et al (2014) Caryophyllene, a CB2 receptor agonist produces multiple behavioral changes relevant to anxiety and depression in mice. Physiol Behav 135:119-124

40. Hirai M, Ito M (2019) Sedative effects of the essential oil and headspace air of Ocimum basilicum by inhalation in mice. J Nat Med 73:283-288. https://doi.org/10.1007/s11418-018-1253-3

41. Anas S, Anton A, Mustarichie R (2010) Identification of compounds in the essential oil of Nutmeg seeds (Myristica fragrans Houtt.) that inhibit locomotor activity in mice. Int J Mol Sci 11:4771-4781

42. Yao QS, Chiou GC (1993) Inhibition of crystallins-induced inflammation in rabbit eyes with five phytogenic compounds. Acta Pharmacol Sin 14:13-17

43. Kirchner K, Wisniewski AJ, Cruz AB, et al (2010) Chemical composition and antimicrobial activity of Hedyosmum brasiliense Miq., Chloranthaceae, essential oil. Rev Bras Farmacogn 20:692-699. https://doi.org/10.1590/S0102-695X2010005000005

44. Coelho-de-Souza L, Leal-Cardoso J, de Abreu Matos F, et al (2005) Relaxant effects of the essential oil of Eucalyptus tereticornis and its main constituent 1,8-cineole on guinea-pig tracheal smooth muscle. Planta Med 71:1173-1175

45. Santos F, Rao V (2000) Antiinflammatory and antinociceptive effects of 1,8-cineole a terpenoid oxide present in many plant essential oils. Phytother Res 14:240-244

46. Teixeira GFD, Júnior RCPL, Silveira ER, et al (2008) Sedative Effect of Eucalyptus Urophylla and E. Brassiana in Mice. Nat Prod Commun 3:1539-1542. https://doi.org/10.1177/1934578X0800300928

47. Galindo LA, de Moraes Pultrini A, Costa M (2010) Biological effects of Ocimum gratissimum L. are due to synergic action among multiple compounds present in essential oil. J Nat Med 64:436-441. https://doi.org/10.1007/s11418-010-0429-2 
Table 1. Phytochemical constituents of Beninese LCEO and comparison of their ratio in LCEOs of different origins

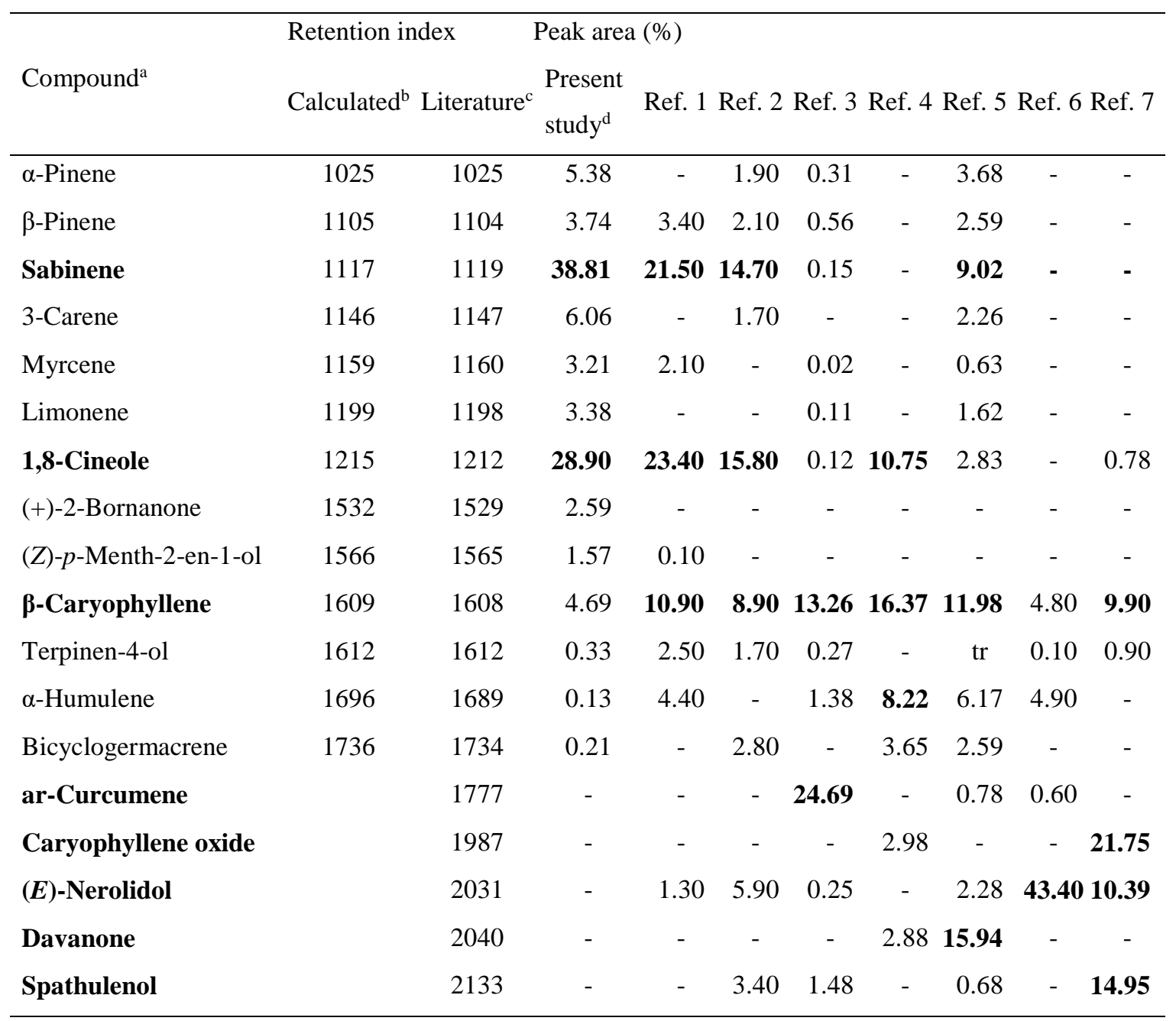

${ }^{a}$ Order of elution determined using a DB-wax column.

${ }^{b}$ Retention index, calculated against C10-C26 $n$-alkanes on a DB-wax column.

${ }^{\mathrm{c}}$ Retention index, taken from the NIST library.

${ }^{d}$ Peak area percentage was determined by calculating the peak area of the FID chromatogram in GC analyses.

Ref. 1: Seme (Rep. of Benin) [18]; Ref. 2: Nigeria [3]; Ref. 3: Cameroon [20]; Ref. 4: India [21];

Ref. 5: Madagascar [20]; Ref. 6: Cuba [24]; Ref. 7: Nigeria [28]; tr: trace; -: not detected. 


\section{Figure Legends}

Fig. 1 Chemical structures of the major constituents of LCEO and fractions

Sabinene (1), 1,8-Cineole (2), ß-Caryophyllene (3), $\alpha$-Pinene (4), Terpinen-4-ol (5), and (+)-2Bornanone (6)

Fig. 2 Total spontaneous motor activity (a) and locomotor activity transition (b) of mice treated with LCEO (0.000004, 0.00004, 0.0004, 0.004, 0.04 or $0.4 \mathrm{mg})$

Data represent the mean \pm SEM of 6 mice. Statistical differences vs. the control group were calculated using ANOVA followed by Dunnett's test. ${ }^{*} p<0.05$.

Fig. 3 Total spontaneous motor activity of mice treated with sabinene and 1,8-cineole (0.000004, 0.00004, 0.0004, 0.004, 0.04 or $0.4 \mathrm{mg}$ ) (a and b respectively)

Data represent the mean \pm SEM of 6 mice. Statistical differences vs. the control group were calculated using ANOVA followed by Dunnett's test. ${ }^{*} p<0.05$.

Fig. 4 Total spontaneous motor activity (a) and locomotor activity transition (b) of mice treated with a mixture of sabinene and 1,8-cineole $(0.00008,0.0008,0.008,0.08$ or $0.8 \mathrm{mg})$ Data represent the mean \pm SEM of 6 mice. Statistical differences vs. the control group were calculated using ANOVA followed by Dunnett’s test. * $p<0.05$. 
<smiles>C=C1CCC2(C(C)C)CC1C2</smiles>

1<smiles>CC12CCC(C(C)(C)C)(OC1)O2</smiles>

2<smiles>C=C1CC/C=C(/C)CCC2(C)CC1CC2C</smiles>

3<smiles>CC1=CCC2CC1C2(C)C</smiles>

4<smiles>CC1=CCC(O)(C(C)C)CC1</smiles>

5

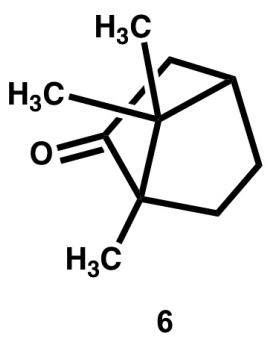

Fig. 1 Chemical structures of the major constituents of LCEO and fractions

Sabinene (1), 1,8-Cineole (2), ß-Caryophyllene (3), $\alpha$-Pinene (4), Terpinen-4-ol (5), and (+)-2Bornanone (6) 


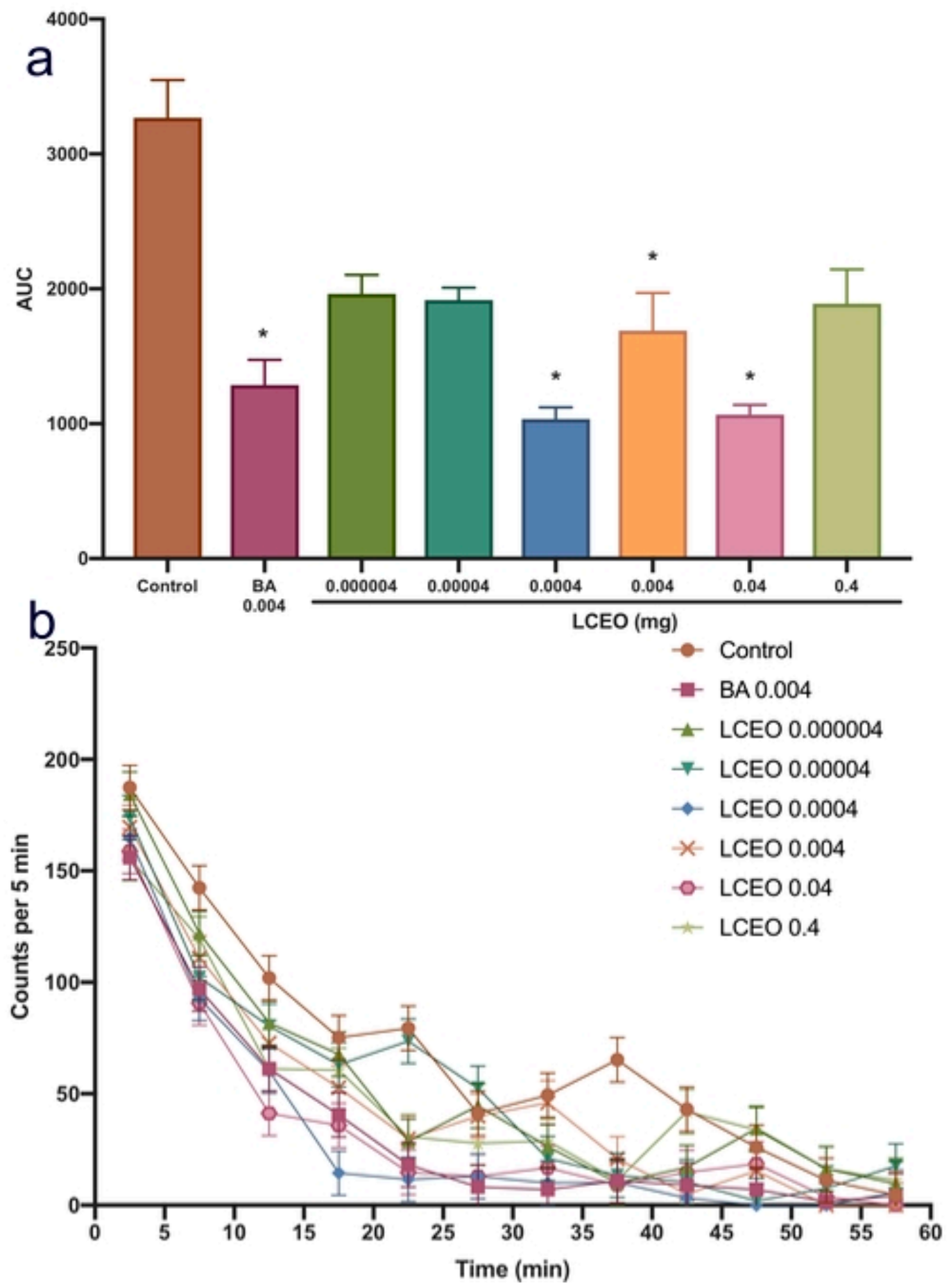

Fig. 2 Total spontaneous motor activity (a) and locomotor activity transition (b) of mice treated with LCEO $(0.000004,0.00004,0.0004,0.004,0.04$ or $0.4 \mathrm{mg})$

Data represent the mean \pm SEM of 6 mice. Statistical differences vs. the control group were calculated using ANOVA followed by Dunnett's test. * $p<0.05$. 

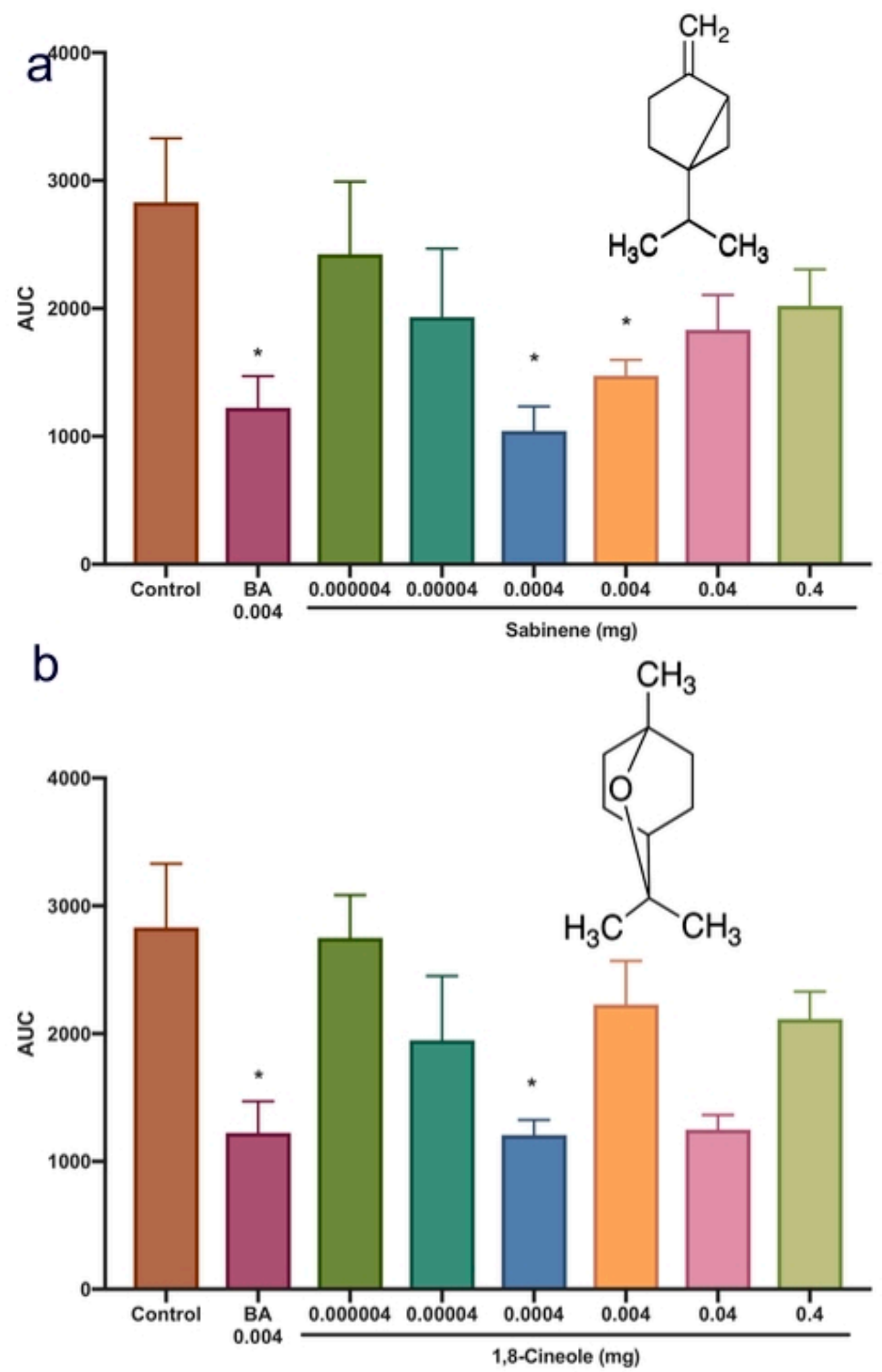

Fig. 3 Total spontaneous motor activity of mice treated with sabinene and 1,8-cineole $(0.000004,0.00004,0.0004,0.004,0.04$ or $0.4 \mathrm{mg}$ ) (a and b respectively)

Data represent the mean \pm SEM of 6 mice. Statistical differences vs. the control group were calculated using ANOVA followed by Dunnett's test. * $p<0.05$. 


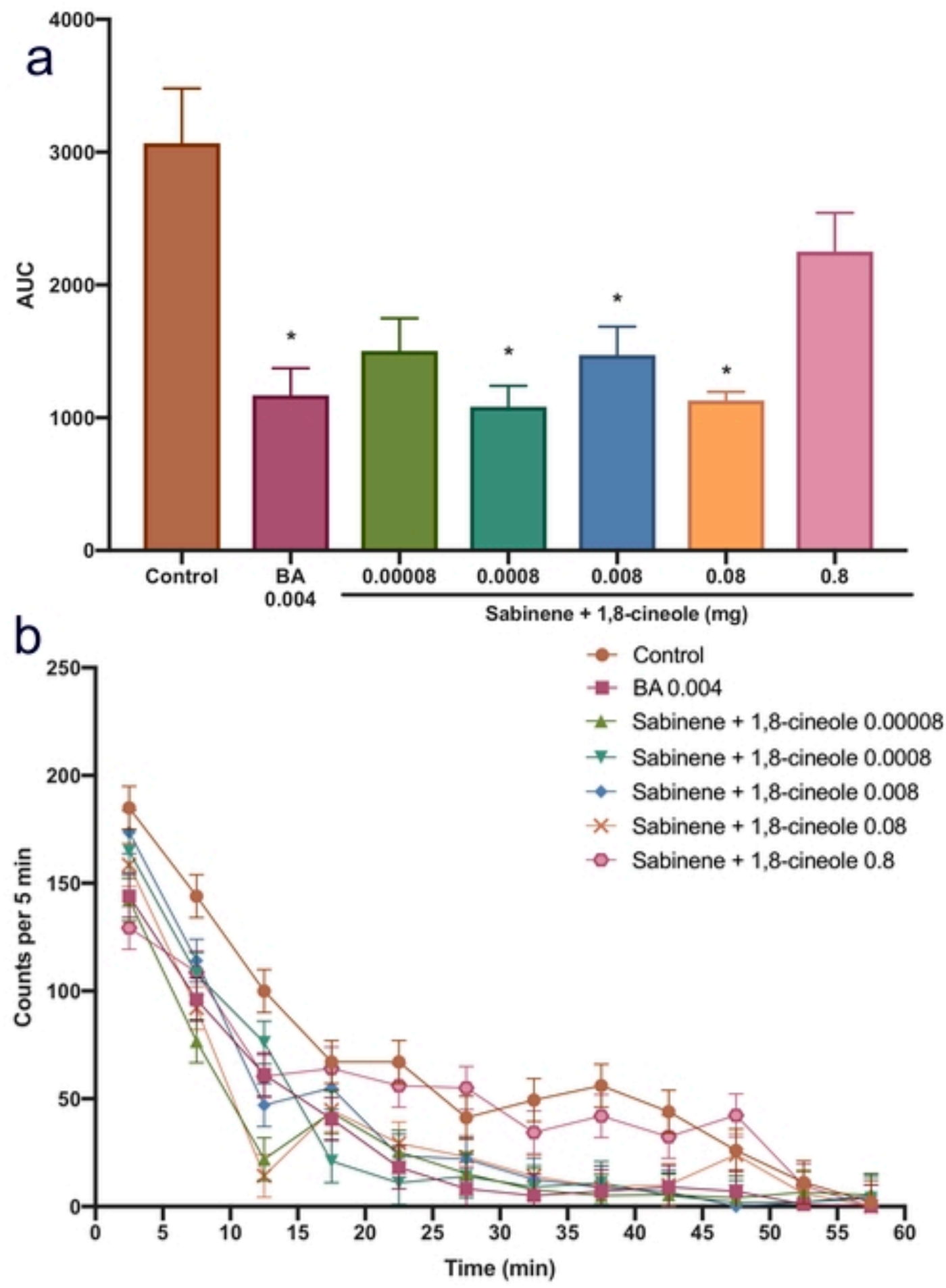

Fig. 4 Total spontaneous motor activity (a) and locomotor activity transition (b) of mice treated with a mixture of sabinene and 1,8-cineole $(0.00008,0.0008,0.008,0.08$ or $0.8 \mathrm{mg})$

Data represent the mean \pm SEM of 6 mice. Statistical differences vs. the control group were calculated using ANOVA followed by Dunnett's test. ${ }^{*} p<0.05$. 


\section{Supplementary data}

Sedative effects of the essential oil from the leaves of Lantana camara occurring in the Republic of Benin via inhalation in mice

Authors: Godfried Dougnon and Michiho Ito*

Department of Pharmacognosy, Graduate School of Pharmaceutical Sciences, Kyoto University, 46-29 Yoshida-Shimoadachi-cho, Sakyo-ku, Kyoto 606-8501, Japan

* Corresponding author:

E-mail: michihoi@pharm.kyoto-u.ac.jp

Tel: $+81-75-753-4506$ 


\section{Contents}

Fig. S1 Leaves of Lantana camara in their natural environment ................................ 3

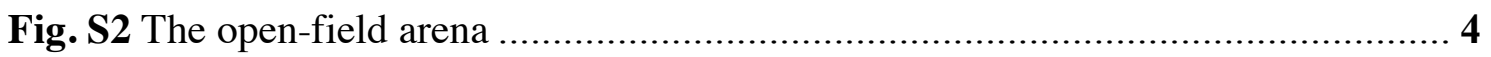

Fig. S3 Total spontaneous motor activity of mice treated with fraction 2 and fraction 1 $(0.000004,0.00004,0.0004,0.004,0.04$ or $0.4 \mathrm{mg}$ ) (a and b respectively). 5 


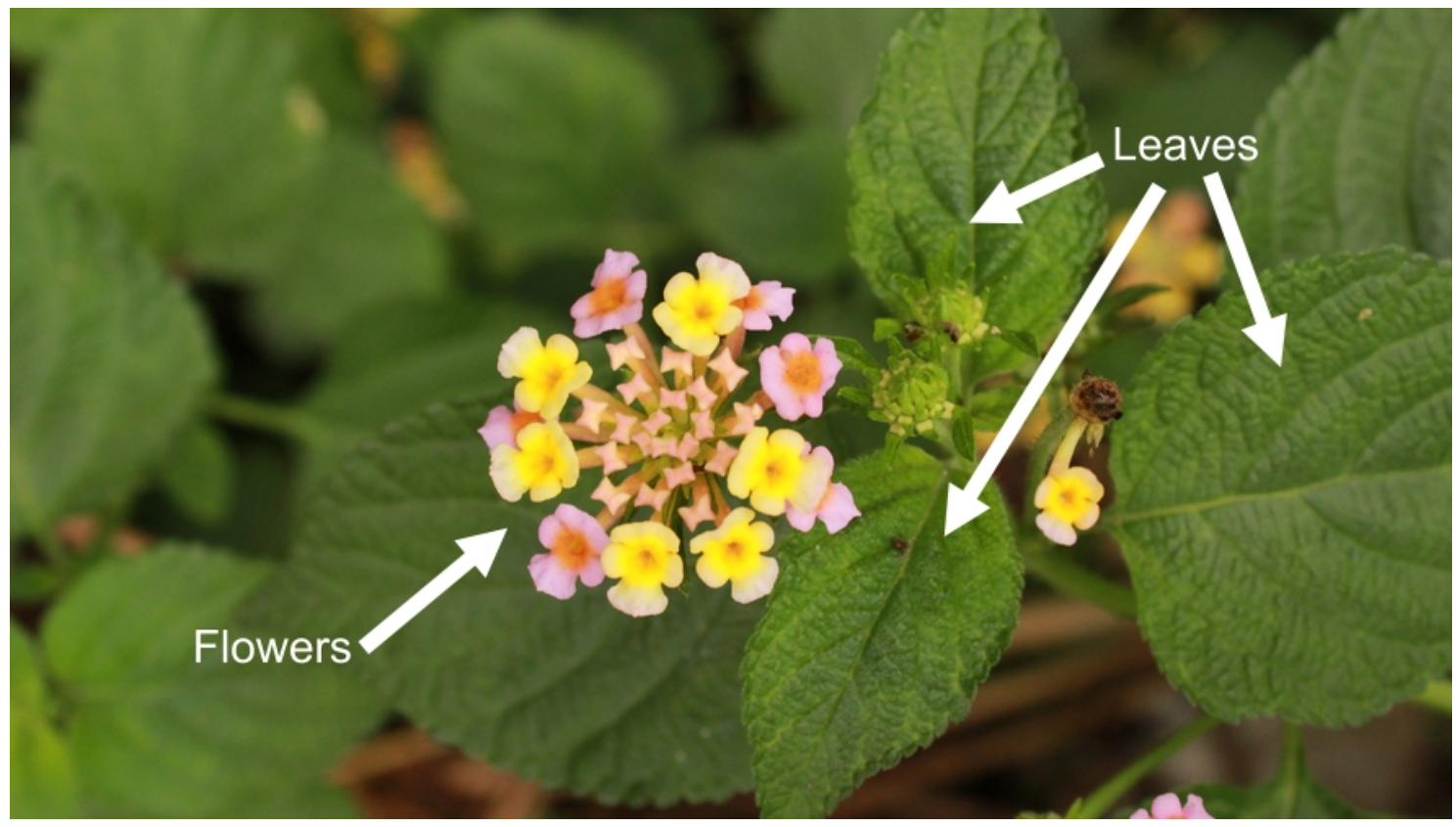

Fig. S1 Leaves of Lantana camara in their natural environment 


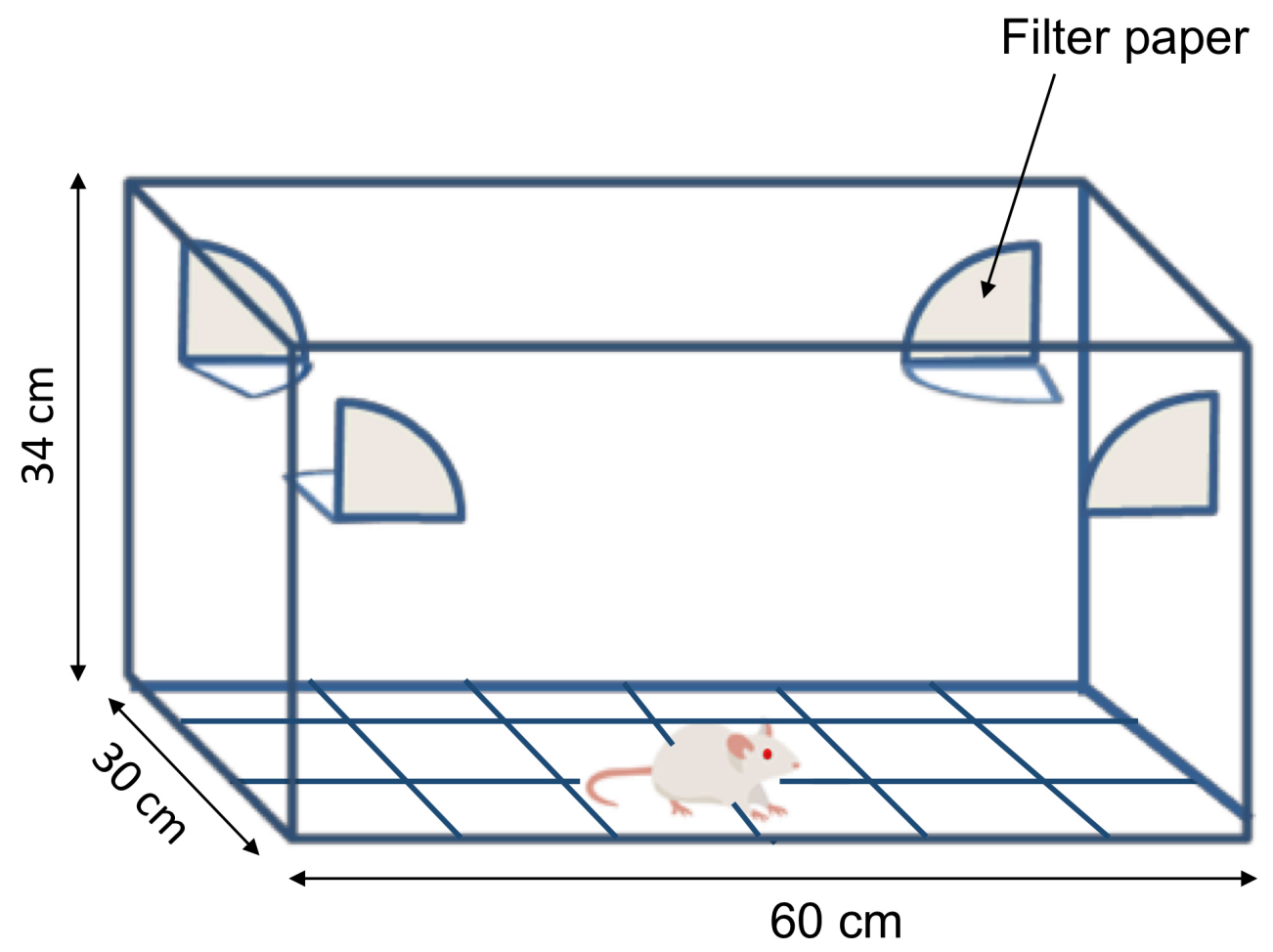

Fig. S2 The open-field arena 

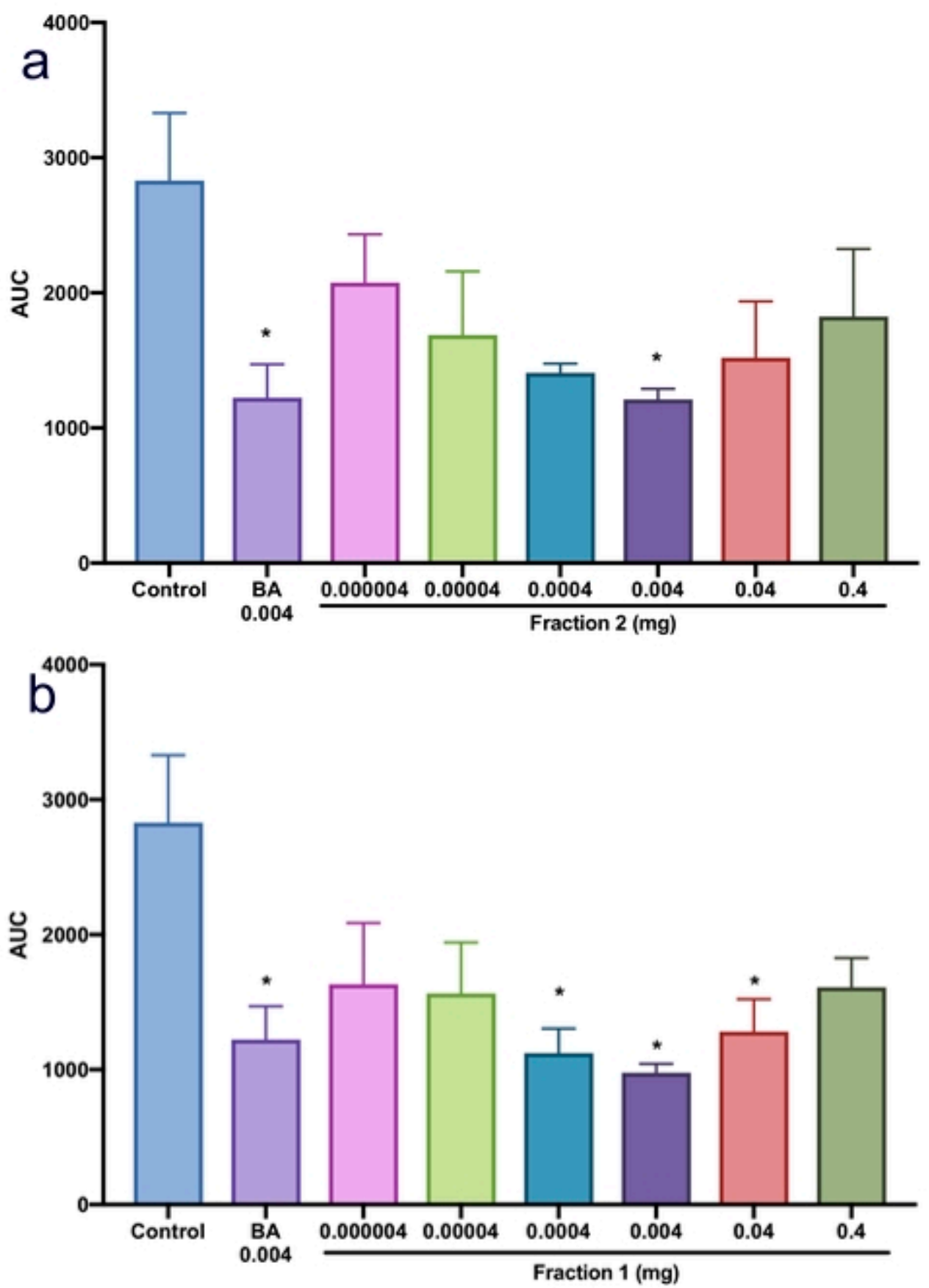

Fig. S3 Total spontaneous motor activity of mice treated with fraction 2 and fraction $1(0.000004,0.00004,0.0004,0.004,0.04$ or $0.4 \mathrm{mg})$ (a and b respectively)

Data represent the mean \pm SEM of 6 mice. Statistical differences vs. the control group were calculated using ANOVA followed by Dunnett's test. * $p<0.05$ 